\title{
REDEVELOPMENT POTENTIAL OF BROWNFIELDS: A-B-C CLASSIFICATION AND ITS PRACTICAL APPLICATION
}

\author{
Lucie Doleželová, Michal Hadlač, Milada Kadlecová, \\ Stanislav Martinát, Milan Polednik
}

\section{Introduction}

The issue of brownfields and their redevelopment raises a wide public debate in many countries within the European Union. Existence of this phenomenon, which is both linked to long historical industrial traditions [16] in this region and recent trends in the society like deindustrialization processes, significantly influenced the character and spatial structures of plenty of cities, towns and villages. Just for the area of the Czech Republic, where also transition of economy in last two decades has to be considered, estimations vary between 8.5 and 11.7 thousands of such sites on areas between 27-38 thousand hectares [4]. These brownfields sites are located in various locations. On one hand, plenty of brownfields could be found in inner parts of large cities, on the other hand some of brownfields after agricultural activities could be found in almost every rural municipality [13]. It is obvious that redevelopment potential of different types of brownfields differ according to location and its consequences (e.g. location within a city, proximity to the center, proximity to highway etc.). But also other factors like political, cultural or environmental issues have to be seriously taken into account too. The proposed paper is trying to follow the theoretical debate on redevelopment potential of individual brownfields and its classification. Application of one of methods (A-B-C classification) on example of set of brownfields in the South-Moravian Region and the Ústí Region of the Czech Republic is employed in the later part of this paper to identify potential of various types of brownfields and to show the practical use of this method.

\section{Rationale behind Brownfields Classification}

Brownfields classification, i.e. their sorting into categories, is the next step that has to be employed after their identification, description and mapping [24]. It has to be stressed that classification in general is largely a theoretical and conceptual task. Sorting of brownfields into categories should be vital for the choice of regeneration strategies and concepts [20]. Several classification systems were developed within research studies both in the Czech Republic ([25], [9], [15]) and many of them in other countries within the European Union (e.g. [1], [21]) or out of Europe (e.g. [23], [10], [11], [12]). Some of these classifications are working with more economic indicators [1], others are more oriented on technical and environmental aspects [21]. Different approaches are also employed if such classification is carried out on the local, regional or even national level [6]. GIS methods (e.g. [22]), where the extent and location of brownfields are considered as the most important factors [13], are very useful for development of brownfields classifications and for modelling of impact of brownfields on neighbourhoods. Such classifications offer support to decision makers to identify individual brownfields or groups of brownfields that are worth to be redeveloped [5] or could also serve as the base for structural help to economically weak regions [18], [19], [26]. 
For example the city of Brno has one of the less practical classification systems. Created as a part of the Phare programme funded project, it contains 9 categories: 1a, 1b, 2a, $2 \mathrm{~b}$ etc...., (which are too complicated and do not define the regeneration potential of the site). Most of them saw a little practical use, for example in directing public funding for brownfield regeneration. In our opinion, the classification recommended in the European Project Cabernet [3] is the most useful for decisions about public funding. This classification, similar to the classification used in the United Kingdom National Brownfield Regeneration Strategy [4], divides brownfields into three A-B-C categories as to their development potential. The A sites are so called self-developing sites. Their regeneration can be realized in the free market economy without the need for public funding (for more comments on importance on market for brownfields redevelopment cf. [21]. The B sites are "potential development" sites which require some (possibly indirect) form of public funding. These projects can be realized only with a marginal profitability, therefore they appear too risky to private investors. Regeneration of the C category "non-developing" sites represents a financial loss for the investor. It is carried out in justified cases (environment protection, safety, real estate market support etc.) with public funding and often by public enterprise. Private enterprise is not interested in $\mathrm{C}$ sites, because the regeneration costs will not guarantee the increase in value of the site that would enable future development. Such investment made by public administration could pay off later, for example if the site becomes suitable for building. Some later studies include a D category of permanently derelict sites [2] that require no investment, but may become regenerated by the process of natural succession. In the conditions of the Czech Republic this category is jokingly referred to as the "selfdestructing" category. There are usually derelict buildings which are gradually (and most often illegally) taken apart for construction materials, and the remnants are overgrown.

The A-B-C classification, commonly known among experts, was used in the document approved by the government of the Czech Republic - the National Strategy for Brownfield Regeneration [4] that was acknowledged by the Government of the Czech Republic. It was not, however, used for public decisions regarding brownfields and their management, because the theory, in our circumstances, is only catching up to practice.

The A-B-C classification is highly informative about the redevelopment potential of brownfields, because the ratio of regeneration costs to the future site value takes in account both the location and the state of the brownfield, see Fig 1.

\section{Fig. 1: Brownfield redevelopment types - the A-B-C Model}

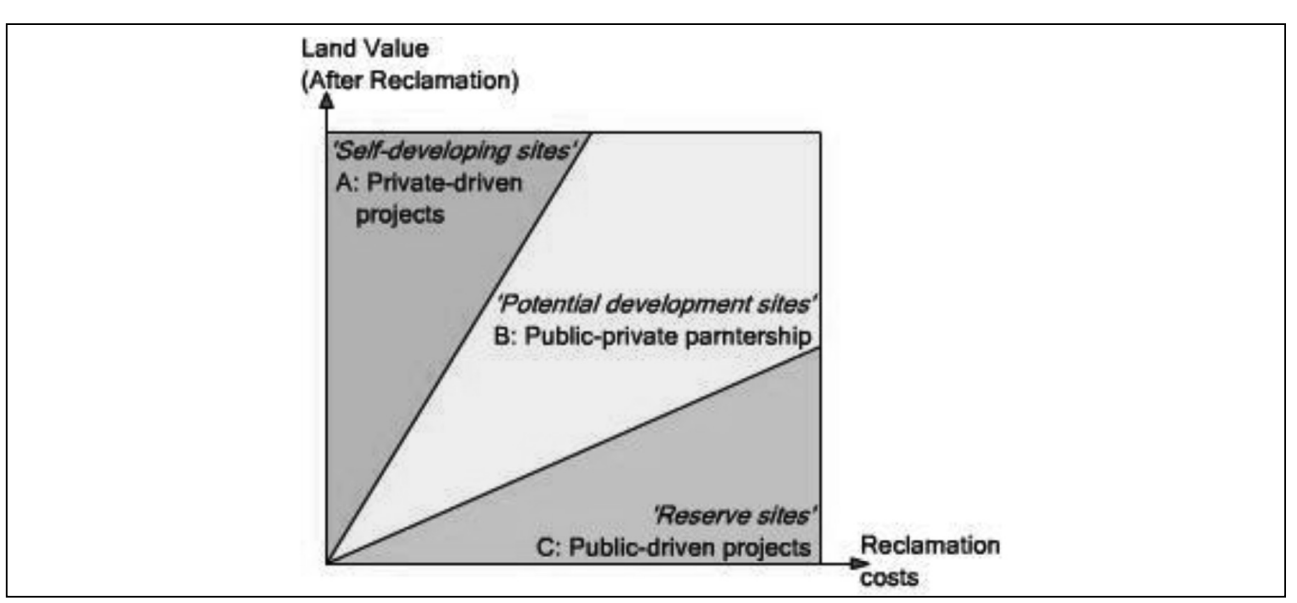

Source: http://www.cabernet.org.uk 


\section{Ekonomie}

A correct classification of a brownfield into the A-B-C category requires not only the knowledge of its current state, but also the knowledge of the intended future use of the site, so that the regeneration costs can be properly assessed. Although we do not know the methods used in various national strategies for brownfield classification, classification results are often used in documents. According to a French strategy from 1980s [7], only an estimated $10 \%$ of sites were in the A category. A Canadian strategy [17] estimated that $60-70 \%$ of all brownfields belong to the B category. The United Kingdom national strategy also uses a classification system. In 2007, the CzechInvest agency concluded the Search Study for Location of Brownfields, executed between 2005 and 2007 in 13 regions out of Prague. The Study mapped 2,355 sites with the total acreage of 10,362 hectares. The purpose of the study was not to achieve a cumulative mapping of all brownfields. It registered only a representative sample of 100,200 or 250 sites per region. Sites ideal for preparation of regeneration projects and possible financing from structural funds were later selected in the so called 2 nd and 3rd stage. This is often overlooked when it comes to interpretation of the study results. Although the study does not yield the total number of brownfields, some of its results present information valid for the entire Czech Republic. The idea to apply economic analysis of the study data for the development of a classification system suggested itself.

\section{The Economic Analysis of the Development Potential Performed on a Sample of Brownfields}

A representative sample of 36 brownfields from the Ústí Region and 44 brownfields from the South Moravian Region was selected for the economic analysis. Similarly to the above mentioned Search Study, sites both centrally located and remote, of varying acreage, various former and future use and different degrees of land coverage were selected. The regions were selected so that both economic situation and location of the region would markedly influence the A-B-C classification of the sites.

The purpose of the study was to evaluate the post-regeneration "commercial potential" of the sites based on the collected data. The resulting post-regeneration plot (or real estate) prices, including investment costs and eventual subvention funding, were compared with real estate market prices typical for the location.

The principal aim of the study was an assessment of economic feasibility of regeneration, i.e. comparison of investment profitability from the investor viewpoint. The result of the analysis was a statement of how many and possibly what kind of projects/sites are realizable on "commercial basis", that is without subventions, and belong to the A category, how many and what kind of projects require public funding and belong to the $\mathrm{B}$ category, and how many and what kind of projects are not realizable even with the assumption of public funding, and therefore belong to the brownfield $\mathrm{C}$ category.

Both general and fairly detailed information about individual sites was collected during the first stage of the Search Study. The data included location identification, description of the acreage and the land coverage of the site, and its former, current and anticipated future use. Ownership of the site was determined, and limitations imposed by natural and technical conditions and zoning. Data on transportation access, existence of ecological burden and eventual investment goals were collected, and a rough estimate of site revitalization costs was produced. This item in the site description caused many difficulties to the Search Study authors. The estimates could significantly deviate from reality either as an overvaluation, or undervaluation. Similarly to the Search Study, sites both centrally located and remote, of varying acreage, various former and future use and different degrees of land coverage were selected. The estimates presented a similar hindrance for the economic analysis, particularly the lack of more detailed sorting of regeneration costs, where the item "real burdens" were omitted, as well as direct and consequential infrastructure costs. Real burdens (ecological burdens) in particular can be realistically estimated for many sites, and although they were mentioned in the site descriptions, they were not quantified. While the estimate of infrastructure investment would be possible in the form of an overall cost fraction relative to acreage, the estimate of consequential investments outside the location, namely those associated with providing transportation access, could pose a problem. Investment needs would have to be adequately checked for all types of infrastructure 
(transportation access of a location is often interconnected with broader transportation problems of its respective municipality). With regard to the cited issues, the final evaluation was focused predominantly towards a general profitability assessment of the investments. The average regional results estimate the general ecological and other real burdens in the amount of $10-15 \%$ of the total regeneration costs (requiring a corresponding increase in grant funds).

\section{The Assessment Method for a Site Development Potential}

A local market price and a real estate saleability coefficient were determined for each site based on its principal function and location, including evaluation of transportation access (the determination of local market price and saleability of real estate was based on source materials from the Regional Information Institute, Ltd., particularly from a database monitoring apartment prices and rent (also known as KISEB - Komplexní Informační Systém Ekonomiky Bydlení - the Complex Information System on Housing Economics), established by the Institute in 2000).

- A synoptic inventory including a location map was prepared for each site.

- The total price of the plot was determined from the site acreage and the market price of the plot per $\mathrm{m}^{2}$ (post-regeneration).

- Total floor space of building structures and floor index were used to determine an estimated reproduction cost of buildings with regard to their function, further adjusted by the average amortization estimate and saleability.

- In individual cases, the investment expenditure for revitalization estimate was compared within building reproduction cost. Cases where revitalization costs exceeded $100 \%$ of market price were marked in the synoptic inventory, as well as cases where the costs represented less than $10 \%$ of market price. Such variability in the revitalization costs indicates dissimilar approaches to revitalization costs assessment.

- A comparison of the pre- and postrevitalization market price was performed, and the need for investments was determined for a $40 \%$ vs. $85 \%$ grant financing scenario.
The result was an evaluation of the investor's net profit or loss with respect to the anticipated market price increase and investment profitability.

Local plot market prices were determined based on residential real estate saleability coefficients (i.e. residential real estate market prices), assuming that a real estate market price equals the building reproduction cost plus the market price of the plot. Known proportions of plot market prices based on their use (industrial, storage, residential, commercial) were also utilized. The saleability coefficient was the starting parameter for investment profitability evaluation. Real estate saleability was determined for each location by the Regional Information Institute, Ltd., which monitors real estate prices in the Czech Republic since 2000. Real estate saleability (saleability coefficient) was determined as the ratio between market price and the reproduction cost (i.e. the building cost minus amortization). It expresses the relationship between building investments and the current price for which the building could be sold at the present time. The saleability coefficient for residential real estate expresses the state of supply and demand equilibrium in a given location. Although it was determined particularly for the residential type of real estate, it would be similar to saleability coefficients of other types of real estate at the time. Saleability coefficients are commonly listed in the regulations of the Ministry of Finance of the Czech Republic on property valuation, e.g. Regulation No. 617/2006 Sb., amending Regulation No. $540 / 2002 \mathrm{Sb}$., on implementation of certain provisions of Act No. 151/1997 Sb., on Property Valuation and Amendments to Certain Acts (Property Valuation Act), as amended. The overall assignment of saleability coefficients to municipalities grouped according to their size in individual districts of the Czech Republic limits the applicability of such coefficients.

If the saleability coefficient is less than 1.0 e.g. 0.5 , then it is probable that the owner can sell the building for a $50 \%$ of the reproduction cost. If such building should be newly constructed, a $100 \%$ of reproduction cost would have to be considered. (Variation of building costs in the Czech Republic depending on location is fairly small.) If the saleability coefficient is greater than 1 , it is safe to assume that the increase of real estate prices above the reproduction cost 


\section{Ekonomie}

will be reflected in an increase of plot prices (e.g. plots in city centres and attractive city locations suitable namely for the commercial, administrative and accommodation use).

Prevalent saleability of real estate with the coefficient value less than 1 reflects:

- a less than ideal location of such real estate (namely before 1990),

- a less than the ideal structure of such real estate (it does not represent the best possible use of the site),

- a surplus of such type of real estate in the entire Czech Republic or on the local market (e.g. agricultural real estate before 1990).

The saleability coefficient gives new investors a clear signal about investment risks for a given location and real estate type. On the other hand it indicates the need for public funding, if such real estate should be sustained.

\section{Economic Analysis Results}

It can be said that the location of the South Moravian Region and Ústí Region within the Czech Republic radically influenced the average plot market prices and the saleability of all real estate (buildings), and therefore also the regeneration profitability of all sites. The total acreage of brownfields subject to the study was approximately 342 ha in the South Moravian Region (44 sites) and 243 ha in the Ústí Region (36 sites). Burden magnitude can be expressed relatively to the number of inhabitants of the Region. The South Moravian one thus exhibits a per capita burden

\section{Tab. 1: Summary results of the economic potential analysis of brownfield sites}

\begin{tabular}{|c|c|c|c|c|}
\hline Line & Indicator & Unit & South Moravian Region & Ústí Region \\
\hline 1 & Site acreage & $\mathrm{m}^{2}$ & $3,418,330$ & $2,431,963$ \\
\hline 2 & Floor space of buildings & $m^{2}$ & 308,939 & 652,373 \\
\hline 3 & Gross estimate of site revitalization costs & mil. CZK & 5,235 & 4,409 \\
\hline 4 & Site revitalization costs as a percentage of reproduction cost & $\%$ & $39 \%$ & $31 \%$ \\
\hline 5 & Average amortization estimate & $\%$ & $69 \%$ & $63 \%$ \\
\hline 6 & Future site use coefficient (average) & - & 0.90 & 0.89 \\
\hline \multicolumn{5}{|c|}{ Prices as of 2007} \\
\hline 7 & Plot market price & $\mathrm{CZK} / \mathrm{m}^{2}$ & 471 & 341 \\
\hline 8 & Saleability coefficient & - & 0.85 & 0.58 \\
\hline 9 & Total plot market price & mil. CZK & 1,610 & 829 \\
\hline 10 & Building reproduction cost without amortization & mil. CZK & 13,430 & 14,319 \\
\hline 11 & Building reproduction cost with amortization & mil. CZK & 4,148 & 5,289 \\
\hline 12 & Market price of buildings before revitalization & mil. CZK & 3,509 & 3,065 \\
\hline 13 & Market price of buildings after revitalization & mil. CZK & 7,719 & 5,587 \\
\hline 14 & Investments needed with $40 \%$ grant funding & mil. CZK & 3,141 & 2,645 \\
\hline 15 & Investments needed with $85 \%$ grant funding & mil. CZK & 785 & 661 \\
\hline 16 & Building market price increase & mil. CZK & 4,210 & 2,522 \\
\hline 17 & Plot market price increase ${ }^{\star}$ & mil. CZK & Not evaluated & Not evaluated \\
\hline 18 & Total real estate market price increase & mil. CZK & 4,210 & 2,522 \\
\hline 19 & Profit/loss on investment at $40 \%$ grant funding & mil. CZK & 1,069 & -124 \\
\hline 20 & Profit/loss on investment at $85 \%$ grant funding & mil. CZK & 3,425 & 1,860 \\
\hline 21 & Investment profitability at $40 \%$ grant funding & $\%$ & $34 \%$ & $-5 \%$ \\
\hline 22 & Investment profitability at $85 \%$ grant funding & $\%$ & $436 \%$ & $281 \%$ \\
\hline
\end{tabular}

* Not evaluated because of missing data on real burdens, ecological burdens in particular. Source: Regional Information Institute, Ltd. 
of $3.02 \mathrm{~m} 2 /$ inhabitant and the Ústí Region only marginally lower value of $2.95 \mathrm{~m}^{2} /$ inhabitant.

The results were processed into the synoptic inventory for each site (a private output), into summary tables containing select information for all sites and into an overview table (Tab. 1).

The average saleability coefficient was 0.85 in the South Moravian Region, 0.58 in the Ústí Region. 38 out of 44 sites were found to have saleability less than 1 in the South Moravian Region. 33 out of 37 sites were found to have saleability less than 1 in the Ústí Region.

Sites with the real estate saleability coefficient greater than 1.1 can be considered unequivocally commercially attractive for investors even without grant funding (unless excessive real burdens or investment risks exist). These sites belong into the category $A$. Another group, classified $B$ according to the Project Cabernet, contains sites with the saleability coefficient equal or smaller than 1.1, but greater than 0.75 . These sites can be sometimes regenerated even without direct public funding (e.g. when public infrastructure is improved, namely transportation access to the site). These sites represent lower internal costs for the investor, or the investment provides comparative supplemental advantages. The fact that in some cases the regeneration costs were not properly estimated needs to be considered. Therefore the category $B$ is defined rather broadly. Remaining sites with the saleability coefficient less than 0.75 make up the group of unprofitable projects, marked by the letter $\mathrm{C}$.

The majority of brownfield sites in both regions fell into the category $\mathrm{C}$. The following table (Tab. 2) presents an overview of the number and acreage of sites and their respective A-B-C classification.

\section{Tab. 2: Classification according to the Project Cabernet}

\begin{tabular}{l|c|c|c|c|c|c|c|c}
\multirow{2}{*}{ Region } & \multicolumn{2}{|c|}{ Category A } & \multicolumn{2}{c|}{ Category B } & \multicolumn{2}{c|}{ Category C } & \multicolumn{2}{c}{ Total } \\
\cline { 2 - 8 } & $\begin{array}{c}\text { Number } \\
\text { of sites }\end{array}$ & $\begin{array}{c}\text { Total } \\
\text { acreage } \\
\text { in } \mathrm{m}^{2}\end{array}$ & $\begin{array}{c}\text { Number } \\
\text { of sites }\end{array}$ & $\begin{array}{c}\text { Total } \\
\text { acreage } \\
\text { in } \mathrm{m}^{2}\end{array}$ & $\begin{array}{c}\text { Number } \\
\text { of sites }\end{array}$ & $\begin{array}{c}\text { Total } \\
\text { acreage } \\
\text { in } \mathrm{m}^{2}\end{array}$ & $\begin{array}{c}\text { Number } \\
\text { of sites }\end{array}$ & $\begin{array}{c}\text { Total } \\
\text { acreage } \\
\text { in } \mathrm{m}^{2}\end{array}$ \\
\hline $\begin{array}{l}\text { South } \\
\text { Moravian }\end{array}$ & 10 & 507,380 & 12 & 544,490 & 31 & $2,366,460$ & 44 & $3,418,330$ \\
\hline Ústí & 2 & 128,997 & 7 & 665,466 & 28 & $1,637,500$ & 37 & $2,431,963$ \\
\hline
\end{tabular}

Source: Regional Information Institute, Ltd.

Sites in city centres or at transport junctions, representing opportunities for business, accommodation, or administrative use were commercially the most attractive for investors. Agricultural real estate (plots or buildings) appeared commercially uninteresting - but their continuing negative development could not be unequivocally anticipated in the long run (witness the recent signs of agriculture production revival).

The average plot market price was found to be $471 \mathrm{CZK} / \mathrm{m}^{2}$ in the South Moravian Region and $341 \mathrm{CZK} / \mathrm{m}^{2}$ in the Ústí Region. The plot market price ranged from 45 to $1,254 \mathrm{CZK} / \mathrm{m}^{2}$ in the Ústí Region and from 98 to $1,397 \mathrm{CZK} / \mathrm{m}^{2}$ in the South Moravian Region.

$40 \%$ grant funding would help achieve profitability in 14 out of 37 sites in the Ústí Region, and in 27 out of 44 sites in the South Moravian Region, but only on the assumption of zero ecological or other real burdens, for example infrastructure costs.

\section{Update for the Year 2012}

The economic analysis was executed in 2007, when the real estate crisis was just looming on the horizon, and did not yet affect the applied real estate price statistics. Real estate prices, particularly residential real estate and plots, grew sharply between 2005 and 2008 (see Fig. 2). The rapid increase of real estate prices boosted the building trade and investors' profits. Increasing residential real estate prices after 2005, coupled with stagnation of rental incomes, led to the decline of annual rates of gross real estate rental income, which was evident in the decline of the building construction activity. The decrease of real estate prices continuing from 2008 until the present time 


\section{Ekonomie}

somewhat curbed the fall of rental incomes, but only by a few percentage points (compared to 2000 , the gross annual return rate is lower by approximately one third, and the net returns capitalization fell even sharper (because maintenance, administration and operation costs grew faster). The fall of real estate prices since 2008, differentiated according to the real estate type, led to a decline of investments and depression of the building industry. Public sources (namely EU grants, not as much government spending which is being curtailed) and the Czech National Bank policy of "cheap money" resulting in a decrease of mortgage rates seem to offset the decline in commercial investments. The principal current result of this particular macroeconomic policy mix is a gross domestic product decline, and most notably a decrease of family consumption and attenuation of the investment portion of public budgets. Abundantly available real estate represents a future burden, as the situation tends to further depress market prices. The effective use of older commercial real estate with high operation costs and excessive proportion of reconstruction costs is difficult under these conditions. This applies to brownfields directly.

\section{Fig. 2: The development of selected real estate indexes in the Czech Republic}

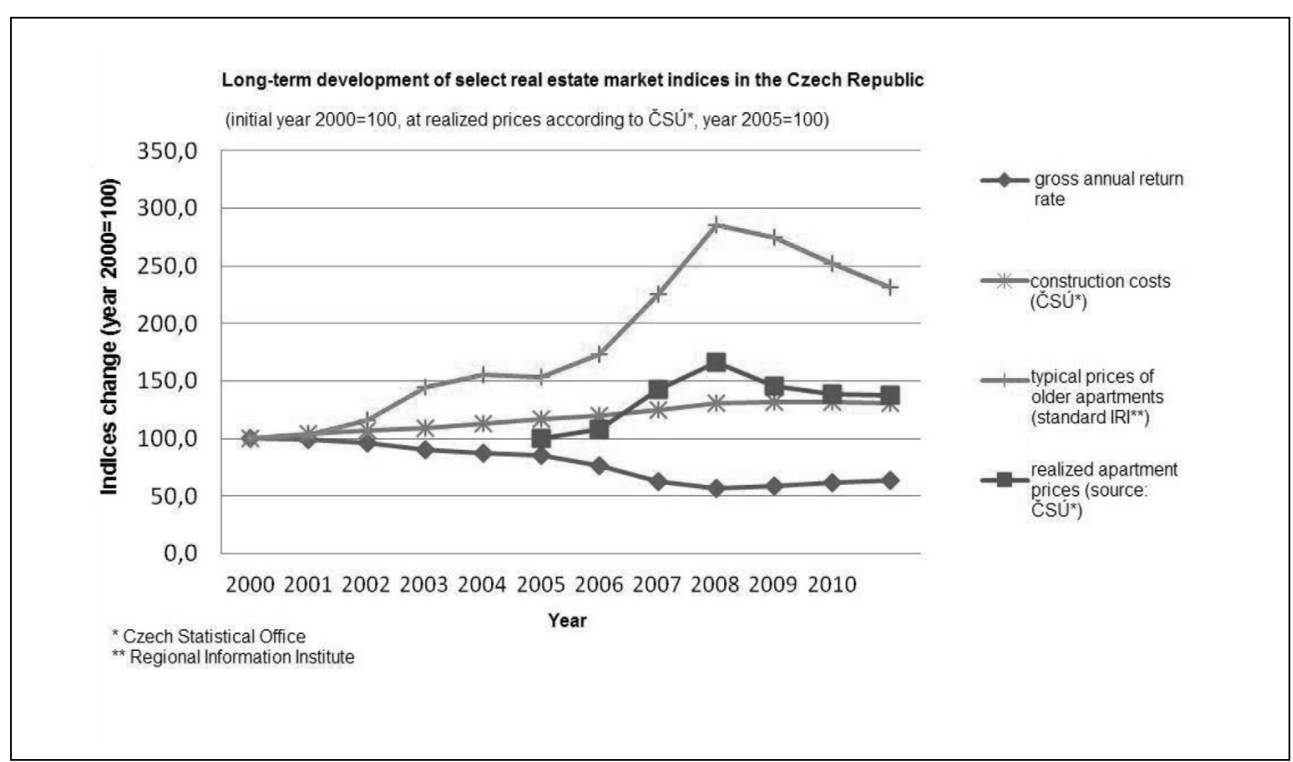

Source: Czech Statistical Office, Regional Information Institute, Ltd.

Following the A-B-C site classification in 2012, a decline in saleability of all sites can be expected, coupled with the decrease of the saleability coefficient and lower return on investment (the decline in net returns). The decline rate is determined particularly by the decline of capitalization (the annual return rate) of commercial projects, which is the highest for apartments (up to $20 \%$ ), and estimated 10 to $15 \%$ for commercial real estate, where it is obviously significantly lower for new constructions and significantly higher for older commercial real estate with high operation costs and excessive proportion of reconstruction costs (which again applies to brownfields).

The crisis has affected more deeply regions with larger systemic problems: the Ústí Region experienced the more pronounced decline of market prices and saleability. The South Moravian Region belongs, on the contrary, to the regions with the less pronounced decline. The return rate by the region is, on the other hand, higher in the Ústí Region, but the (relatively) higher returns there come with 
higher enterprise risks and the deeper decrease of real estate prices, and therefore worse future prospects.

Further changes since 2007 necessitate an update of location significance of individual sites relative to new development hubs and corridors. This concerns principally sites near the highway D8 in the Ústí Region and proximity to the Žatec-Havrañ-Lovosice industrial zone, where the supply of greenfield construction plots dampens the interest in brownfields. The South Moravian Region is in a more stable situation.

Impact of the economic depression on commercial real estate and concomitant increases of enterprise risks lead to the conclusion that the limit values of the saleability coefficient a synthetic criterion for the assessment of site development potential - will require an adjustment. In the current situation it would be appropriate to move up the limit values of the saleability coefficient for A-B-C classification (for the category A greater than 1.1 etc).

The current brownfield market is very narrow, if not dead. Most brownfield site owners have no choice but to wait until the situation improves, while in many cases they will have to adjust their expectations of the income from an eventual brownfield sale.

\section{Adjustment of Grant Funding Programmes for the Brownfield Regeneration}

The approaching end of the 2007-2013 programming period will mark the conclusion of the first, and likely the last, massive influx of EU funding into the Czech Republic. A period of intensive preparation of funding programmers for the support of brownfield regeneration transpired in 2006 during the time of rapid real estate price increases. Owners, developers and investors were attracted to investment into brownfields, and funding programs were supposed to accommodate the process. In the final version of most programs, developers were excluded from grant funding of brownfield regeneration projects, and the principle of funding gap was abolished. In addition to grant funding programmes for brownfield redevelopment, the Real Estate Programme, a part of the Operational Programme Enterprise and Innovation (Podnikání a Inovace), has become the most significant brownfield regeneration programme. To-date the Real Estate Programme has allocated CZK 11 billion, the majority of which had been used for commercial real estate regeneration by small or medium-size manufacturing businesses. Aside of the Real Estate Programme, organizations governed by public law, namely municipalities, can also acquire grant funding for brownfield regeneration through regional operational programmes. However, the project numbers and allocation amounts in these programmes are significantly lower. Grant funding is also utilized for reconstruction or regeneration of farms or agribusiness through the Rural Development Programme (Program rozvoje venkova).

It is important to point out that the group of brownfields identified in the Search Study of 2007 does not overlap with the group of brownfields covered by grant funding programmes almost at all. The reason is that grant applicants, most often entrepreneurs, are interested in business profitability, and if they opt for brownfield regeneration, they prefer well located sites free of obstacles in the form of massive contamination or property rights complications. Consequently the grant funding supports most often the regeneration of A- or B-type sites, which theoretically would not need such support, or it could be effected in another than direct financing form. The only Regional Operational Programme in the MoravianSilesian Region intended for pre-redevelopment of brownfield sites via demolitions and land reclamation, which could be applicable also for C-type sites, is not achieving successful allocations.

\section{Conclusion}

The economic study of brownfield redevelopment potential in the Ústí Region and the South Moravian Region has shown that C-type sites are the most prevalent brownfield category. In structurally challenged regions this category far outnumbers the category B. Economically stronger regions have a higher number of B-type sites, yet only approximately $10 \%$ of brownfields fall into the category $A$, which corresponds with the estimate given in the above quoted eighties French regeneration strategy. Contemporary funding programmes are adjusted in such way that they support namely "ready" regeneration projects, often on 


\section{Ekonomie}

A-type brownfields. This approach, where regeneration is supported by project selection instead of systematically, follows the regeneration pattern typical for West European countries in the eighties. It is a natural course of progress. The Czech Republic will apparently miss the chance to regenerate the problematic brownfields in the category $\mathrm{C}$ while there is the opportunity to draw a large volume of financial support from the European Union. Public administration is not ready to take this step at any rate, because systematic brownfield classification was not performed, priorities among the C-type sites were not established (The Operational Programme Environment (Životní prostředí), on the other hand, has met its goals in the clean-up decontamination area, because classification and setting of priorities were its part, and it is not even clear who should be performing these tasks. Only hope remains that the funded projects contribute to a better look of our cities, villages and landscape, and at least partially improve the situation on the commercial real estate market. Municipalities will be left with a number of problem sites with many ecological and other burdens depressing the value of real estate in their neighbourhoods. For the sake of future, when massive public support for regeneration cannot be expected, it is desirable that system measures are put in place that would assure more effective support to brownfield regeneration, for example in the sphere of urban planning and development as well as in the fiscal sphere.

The outcome of Project NPV II No. $2 D 06025$ "New Institutional Instruments for Land Development and Plot Preparation in Problem Areas Focused on Revitalization of Unused Buildings and Plots", section Economic analysis of development potential of a brownfield sample in the Ústí Region and the South Moravian Region, executed in 2007, adapted in 2012.

This paper was supported by the Ministry of Education, Youth and Sports within the Institutional Support for Long-term Development of a Research Organization in 2014 (School of Business Administration in Karvina, Silesian university in Opava)

\section{References}

[1] BARTKE, S. Valuation of Market Uncertainties for Contaminated Land. International Journal for Strategic Property Management. 2011, Vol. 15, No. 4, pp. 356-378. ISSN 1648-715X.

[2] BUTZIN, B., FRANZ, M., NOLL, H.-P. Strukturwandel im Ruhrgebiet unter Schmrumpfungsbedingungen. Patchwork-Managemen als Herausforderung. Zetschrift für Wirtschaftsgeographie. 2006, Vol. 50, No. 3/4, pp. 258-276. ISSN 0044-3751.

[3] CABERNET TEAM. Sustainable Brownfield Regeneration: Cabernet Network Report. University of Notthingham, 2006. 138 p.

[4] CZECHINVEST AGENCY. National Strategy for Brownfield Regeneration (Národní strategie regenerace brownfieldů). Prague: Ministry of Industry and Trade, 2008, $13 \mathrm{p}$.

[5] ČIHÁKOVÁ AGUILAR, S. Decision making and brownfields management. $E+M$ Ekonomie a Management. 2009, Vol. 12, No. 3, pp. 19-32. ISSN 1802-8470.

[6] DE SOUSA, C.A. Turning brownfields into green space in the City of Toronto. Landscape and Urban Planning. 2003, Vol. 62, No. 4, pp. 181-198. ISSN 0169-2046.

[7] DATAR. Les grandes friches industrielles. Report of a team led by J.P. Lacaze, La Documentation francaise, Paris, 2003, $149 \mathrm{p}$.

[8] ENGLISH PARTNERSHIPS. Towards a National Brownfield Strategy. London: The National Regeneration Agency, 2003. 36 p.

[9] FRANTÁL, B., KUNC, J., NOVÁKOVÁ, E., KLUSÁČEK, P., MARTINÁT, S., OSMAN, R. Location matters! Exploring brownfields regeneration in a spatial context (case study of the South Moravian Region, Czech Republic). Moravian Geographical Reports. 2013, Vol. 21, No. 2, pp. 5-19. ISSN 1210-8812.

[10] CHEN, Y., HIPEL, K.W., KILGOUR, D.M., ZHU, Y. A strategic classification support system for brownfield redevelopment. Environmental Modelling \& Software. 2009, Vol. 24, Iss. 5, pp. 647-654. ISSN 1364-8152.

[11] CHENG, F., GEERTMAN, S., KUFFER, M., ZHAN, Q. An integrative methodology to improve brownfield redevelopment planning in Chinese cities: A case study of Futian, Shenzhen. Computers, Environment and Urban Systems. 2011, Vol. 35, No. 5, pp. 388-398. ISSN 0198-9715.

[12] CHRYSOCHOOU, M., BROWNA, K., DAHALA, G., GRANDA-CARVAJALB, K., SEGERSONB, K., GARRICKA, N., BAGTZOGLOUA, A. A GIS and indexing scheme to screen brownfields for area- 
wide redevelopment planning. Landscape and Urban Planning. 2012, No. 105, pp. 187-198. ISSN 0169-2046.

[13] KLUSÁČEK, P., KREJČÍ, T., MARTINÁT, S., KUNC, J., OSMAN, R., FRANTÁL, B. Regeneration of agricultural brownfields in the Czech Republic Case study of the South Moravian Region. Acta Universitatis Agriculturae et Silviculturae Mendelianae Brunensis. 2013, Vol. 61, No. 2, pp. 549-561. ISSN 1211-8516.

[14] KRAFT, J. Úloha trhu při systematické revitalizaci brownfields. E+M Ekonomie a Management. 2005, Vol. 8, Iss. 4, pp. 28-33. ISSN 1212-3609.

[15] KRZYSZTOFIK, R., KANTOR-PIETRAGA, I., SPÓRNA, T. A Dynamic View on the Typology of Functional Derelict Areas. A Research Proposal. Moravian Geographical Reports. 2013, Vol. 21, No. 2, pp. 20-35. ISSN 1210-8812.

[16] NAVRÁTIL, J., PÍCHA, K., HŘEBCOVÁ, J. The importance of historical monuments for domestic tourists: The case of South- Western Bohemia (Czech Republic). Moravian Geographical Reports. 2011, Vol. 18, No. 1, pp. 45-61. ISSN 1210-8812.

[17] NRTEE. Cleaning up the Past, Building the Future: A National Brownfield Redevelopment Strategy for Canada. Ottawa: National Round Table on the Environment and the Economy, 2003. 93 p. ISBN 1-894737-05-9.

[18] RYDVALOVÁ, P. Možnosti regenerace vybrané hospodářsky slabé oblasti. E+M Ekonomie a Management. 2006, Vol. 9, Iss. 2, pp. 49-57. ISSN 1212-3609.

[19] RYDVALOVÁ, P., ŽIŽKA, M. Návrh systému hodnocení projektů z hlediska dopadu výsledků jejich realizace na hospodářsky slabé oblasti. E+M Ekonomie a Management. 2007, Vol. 10, Iss. 1, pp. 33-46. ISSN 1212-3609.

[20] SAYAH, S.M. Prioritizing Brownfields Redevelopment in the City of Kingston, Ontario. A Report submitted to the School of Urban and Regional Planning. Kingston: Queen's University, 2002.

[21] SCHÄDLER, S., MORIO, M., BARTKE, S., FINKEL, M. Integrated planning and spatial evaluation of megasite remediation and reuse options. Journal of Contaminant Hydrology. 2012, Vol. 124, No. 1-4, pp. 88-100. ISSN 0169-7722.

[22] SUN, W., JONES, B. Using multi-scale spatial and statistical analysis to assess the effects of brownfield redevelopment on surrounding residential property values in Milwaukee County, USA. Moravian Geographical Reports. 2013, Vol. 21, No. 2, pp. 56-64. ISSN 1210-8812.

[23] THOMAS, M.R. A weighted, multi-attribute, site prioritization and selection process for brownfield redevelopment. Environmental Practice. 2002, Vol. 4, Iss. 2, pp. 95-106. ISSN 1466-0466. [24] VOJVODÍKOVÁ, B. Colliery brownfields and the master plan of Ostrava. Moravian Geographical Reports. 2005, Vol. 13, No. 2, pp. 49-56. ISSN 1210-8812.

[25] VOJVODÍKOVÁ, B., POTUŽNÍK, M., BÜRGERMEISTEROVÁ, R. The database on brownfields in Ostrava (Czech Republic): Some approaches to categorisation. Moravian Geographical Reports. 2011, Vol. 19, No. 4, pp. 50-60. ISSN 1210-8812.

[26] TVRDON, M., TULEJA, P., VERNER, T. Economic performance and the labour market in the context of the economic crisis: Experience from the Visegrad Four countries. E+M Ekonomie a Management. 2012, Vol. 15, Iss. 3, pp. 16-31. ISSN 1212-3609.

Mgr. A. Lucie Doleželová, Ph.D.

IREAS, Institut pro strukturální politiku o.p.s. lucie.dolezel@gmail.com

Ing. arch. Michal Hadlač

IRI, Institut regionálních informací, s.r.o.

Ing. Milada Kadlecová

IRI, Institut regionálních informací, s.r.o.

Mgr. Stanislav Martinát

Silesian university in Opava

School of Business Administration in Karvina

Department of Economics martinat@opf.slu.cz

RNDr. Milan Polednik

IRI, Institut regionálních informací, s.r.o. 


\section{Ekonomie}

\section{Abstract}

\section{REDEVELOPMENT POTENTIAL OF BROWNFIELDS: A-B-C CLASSIFICATION AND ITS PRACTICAL APPLICATION

\author{
Lucie Doleželová, Michal Hadlač, Milada Kadlecová, Stanislav Martinát, Milan \\ Polednik
}

Brownfields significantly influence the contemporary character of the majority of cities, towns and villages not only in the Czech Republic, but Europe wide. It is obvious that potential of individual brownfields to be redeveloped differs according to various factors. As a consequence of existence of thousands of brownfields classification of such sites has to be developed to enable their sorting and selecting for redevelopment. The majority of experts concerned with brownfields are familiar with the theoretical model of brownfield types $A-B-C$ introduced by the Cabernet Project, funded by the European Union. This classification of brownfields according to their redevelopment potential could be applied in decision making on necessity of public funding for individual brownfields redevelopment projects. This proposal, however, has two caveats: The first one lies in the classification method used to sort brownfields into the individual categories. The second lies in applying the classification within the system of subvention programmes where regeneration has often different goals. This paper follows the theoretical debate on brownfields classification in its first part; the second part is devoted to analysis of the $A-B-C$ model and its practical application on set of brownfields on the example of the South Moravian and Ústí Region (the Czech Republic). More than 20 various indicators were employed to evaluate redevelopment potential of studied brownfields.

Key Words: Brownfields, redevelopment potential, A-B-C classification, Czech Republic.

JEL Classification: O18, R12, R58.

DOI: 10.15240/tul/001/2014-2-003 